\title{
IMPACTS OF INTERNATIONAL TRADE AND FDI ON THE CONSUMPTION OF RENEWABLE ENERGY: CASE IN ASEAN COUNTRIES
}

\author{
THIEU MANH NGUYEN ${ }^{1}$, CHINH HONG NGUYEN ${ }^{2} \&$ DINH TRAN NGOC HUY ${ }^{3}$ \\ ${ }^{1,2}$ The Academy of Finance, Hanoi, Vietnam \\ ${ }^{3}$ Banking University HCMC, Ho Chi Minh City, Vietnam- International University of Japan, Japan
}

\begin{abstract}
Renewable energy will be a valuable energy source for future generation and need to be protected and invested smartly. The social, environmental, and economical problems can be omitted by use of renewable energy sources, because these resources are considered as environment-friendly, having no or little emission of exhaust and poisonous gases.

This paper aims to investigate the role of international trade, real output, financial development, foreign direct investment (FDI), and innovation on the consumption of renewable energy (RE) in ASEAN countries of the world. We find that positive nexus among the international trade, real output, financial development, foreign direct investment (FDI) innovation and consumption of RE. The present study provides the guideline to regulators that they must form the regulation to restrict the consumption of $R E$ in the presence of international trade, real output, financial development, foreign direct investment (FDI), and innovation. This study also implies further researches to recommend more effective solutions for the linkage between FDI and financial development for renewable energy for economic growth in a sustainable direction.

KEYWORDS: Renewable Energy (RE), RE Consumption, Economic Growth, Sustainability, International Trade, Real Output, Financial Development, FDI, Innovation
\end{abstract}

Received: Jun 09, 2020; Accepted: Jun 29, 2020; Published: Aug 07, 2020; Paper Id.: IJMPERDJUN2020693

\section{INTRODUCTION}

Nadia and Seeman (2016) examines the link between foreign direct investment (FDI) and energy demand. FDI is a source of financing that allows businesses to grow. At the same time, FDI can be a source of innovation that promotes energy efficiency. Existing evidence on the impact of aggregate FDI inflows on energy consumption is scarce and inconclusive. The results point broadly to an energy consumption-reducing effect with respect to nonrenewable sources of energy and energy consumption-augmenting effects with respect to renewable energy. They find that these effects vary in magnitude and significance by sectoral FDI.

Thus, this study is going to test the nexus among international trade, real output, financial development, FDI, innovation, and consumption of RE in the ASEAN countries with the help of GMM to fix the issues of heteroscedasticity and serial correlation.

Table 1 shows the potential of RE in ASEAN countries of the world, and statistics show that these countries have sources of solar energy that is used to produce the electric energy round 977KWH through natural resources, 6.105KWH through technical and 305KWH from economical sources. In addition, these countries have sources of solar energy that is used to produce the thermal energy round $80 \mathrm{M}$ through natural resources, 500M through technical and 25M from economical sources. Moreover, these countries have sources of hydropower energy 
that is used to produce the electric energy round $430 \mathrm{KWH}$ through natural resources, $215 \mathrm{KWH}$ through technical and 124.5KWH from economical sources. Furthermore, these countries have sources of wind energy that is used to produce the electric energy round 400KWH through natural resources, 110KWH through technical and 50KWH from economical sources. Similarly, these countries have sources of direct energy (offshore) that is used to produce the electric energy round $150 \mathrm{KWH}$ through natural resources, and 18KWH through technical. Likewise, these countries have sources of geothermal energy that is used to produce the electrical energy round $1.4 \mathrm{KWH}$ from economical sources. In addition, these countries have sources of geothermal energy that is used to produce the thermal energy round $31.500 \mathrm{M}$ through natural resources, $7.500 \mathrm{M}$ through technical and 2.843M from economical sources. Finally, these countries have sources of bio mass-energy that is used to produce the electric energy round $120 \mathrm{KWH}$ through natural resources, 50KWH through technical and $32 \mathrm{KWH}$ from economical sources.

Table 1: Renewable Energy Potential in ASEAN Countries

\begin{tabular}{|l|l|c|c|c|}
\hline \multicolumn{1}{|c|}{ Energy Type } & \multicolumn{1}{c|}{ Usage Purpose } & Natural Capacity & Technical & Economical \\
\hline Solar Energy & Electric (Billion KWH) & 977.000 & 6.105 & 305 \\
\hline & Thermal (Mtoe) & 80.000 & 500 & 25 \\
\hline Hydropower & Electric (Billion KWH) & 430 & 215 & 124.5 \\
\hline Wind Energy & Electric (Billion KWH) & 400 & 110 & 50 \\
\hline Direct Energy-Off shore & Electric (Billion KWH) & 150 & 18 & --- \\
\hline Geothermal Energy & Electric (109 KWH) & --- & --- & 1.4 \\
\hline & Thermal (Mtoe) & 31.500 & 7.500 & 2.843 \\
\hline Bio Mass Energy & Total (Mtoe) & 120 & 50 & 32 \\
\hline
\end{tabular}

\section{LITERATURE REVIEW}

\section{Consumption of Renewable Energy (RE)}

Advances in renewable energy technologies and growing cost-competitiveness have strengthened the business case of renewables and opened new opportunities for countries to transform their energy systems. This study demonstrates that the benefits of scaling up renewable energy surpass cost competitiveness. Increased deployment can meet the energy needs of a growing population, drive development and improve well-being, while reducing greenhouse gas emissions and increasing natural resource productivity. It provides empirical evidence that economic growth and environmental conservation are fully compatible, and that the conventional consideration of trade-o"s between the two is outdated and erroneous (IRENA, 2016).

Moreover, the usage of energy that is produced by the country with the help of solar, wind, and water resources is said to be consumption of RE (Teleke, Baran, Bhattacharya, \& Huang, 2010). Thus, consumption of RE is necessary for economic growth of the country because it increases the production level of the country and this paper used it as prime variable in the study.

\section{International Trade}

The trade among the different countries of the world in exchange for products and services is known as international trade. Moreover, "international trade is the exchange of capital, goods, and services across international borders or territories. In most countries, such trade represents a significant share of gross domestic product (GDP)” (pp-730) (Zhang, Jiang, et al., 2017). In addition, international trade refers to the exchange of products and services among different nations of the world that enhance the GDP of the country and also play a vital role in the economic development of the country. It increases the trade among the countries in terms of import and export which produce the foreign sources of the income for the country 
(Barbier, Barbier, Bishop, \& Aylward, 2019). Thus, international trade is necessary for economic growth of the country because it increases the production level of the country and this paper used it as predictor in the study.

\section{Real Output}

Real output means the production of the country that is adjusted with an inflation factor of the country and used as a real GDP of the country. In addition, "real output is nominal output of a country, adjusted for inflation. From Wikipedia: Output is the quantity of goods or services produced in a country in a given period of time The given period of time is usually per year, and the quantity of goods and services (G\&S) s valued in terms of \$” (pp-1208) (Dogan \& Turkekul, 2016).

\section{Financial Development}

The development of the country in respect of the finance through increasing their level of productivity and economic activities is known as financial development in the country (Beck, Demirgüç-Kunt, \& Levine, 2010).

Eren et al. (2019) investigates the impact of financial development and economic growth on renewable energy consumption in India. The causality test results suggest that renewable energy consumption and economic growth are financial development driven in the long run and there is a bidirectional causality between renewable energy consumption and economic growth in India.

Anton and Nucu (2020) show that capital market development does not influence renewable energy consumption in the new EU Member States. Our empirical results give valuable insights into how best to deploy capital in the renewable sector, in order to provide cost-competitive options to customers, with the final objective of expanding higher value-added services.

\section{Foreign Direct Investment (FDI)}

Moreover, FDI means the investment of individuals and firms of other countries to the home country. This type of investment can take place when the individual or firms of other countries are interested in establishing their business in our home countries to generate revenue from our economy (Tang \& Tan, 2015).

Next, Liu et al. (2016) demonstrate that FDI renewable energy technology spillover has positive impacts on China's energy industry performance. It can also be found that the technology spillover effects are more obvious in economic and technological developed

Regions. Finally, four suggestions are provided to enhance energy industry performance and promote renewable energy technology spillover in China.

Nadia and Seema (2016) point broadly to an energy consumption-reducing effect with respect to non-renewable sources of energy and energy consumption-augmenting effects with respect to renewable energy. They find that these effects vary in magnitude and significance by sectoral FDI.

Then, Polat (2018) stated that although FDI is a source of financing in both developed and developing countries, it is also known as a source of innovation that could reduce the demand for energy. Thus, recent studies have started to focus on isolating the effect of FDI on energy consumption in the host country. However, the debate so far is inconclusive. The main objective of this study is to measure the effect of FDI on renewable and non-renewable energy consumption in 85 
developed and developing countries from 2002 to 2014, employing a dynamic panel data method. The study demonstrated that FDI reduces energy consumption in developed countries but has no effect on energy consumption in developing countries. The study confirmed that the openness index and energy prices also explain energy consumption within developed countries.

\section{Innovation}

Pece et al. (2015) mentioned the innovation, $R \& D$ expenditures and the investments in technology are premises for ensuring competitiveness and progress, and through them a sustainable economic growth.In order to quantify the innovation they have used various variables, such as number of patents, number of trademarks, R\&D expenditures. The results provide evidence of a positive relationship between economic growth and innovation.

Innovation refers to developing new ideas, products, and fields that may help the country to trade globally. This can help in the gaining of competitive advantage in the market nationally and internationally (Nambisan, Lyytinen, Majchrzak, \& Song, 2017).

\section{International Trade and Consumption of RE}

Veena (2013) mentioned while costs are coming down, domestic policies may either encourage or tilt the playing field against renewables. First, explicit trade barriers and restrictions on RE equipment, such as import tariffs, can unnecessarily raise the costs to firms of procuring such equipment. Second, incentives for RE generation in one country can affect deployment and trade opportunities for other countries.

The use of RE is depended upon the international trade in which a country needs more products to sell in the international market, and for the production of that product, the country uses the RE. In addition, international trade is a vital element that increases the usage of RE in the country to produce products to compete in the international market (Jensen, 2017).

H1: There is positive nexus among the international trade and consumption of RE in ASEAN countries.

\section{Real Output and Consumption of RE}

Real output is the vital element that increases the usage of RE in the country to produce the products to compete in the market. Thus, real output is considered a vital source of high RE consumption in the country and based on this literature the current study has made the hypothesis as follows:

H2: There is positive nexus among the real output and consumption of RE in ASEAN countries.

\section{Financial Development and Consumption of RE}

H3: There is positive nexus among the financial development and consumption of RE in ASEAN countries.

\section{FDI and Consumption of RE}

FDI is the vital element that increases the usage of RE in the country to produce the products to compete in the market. Thus, FDI is considered a vital source of high RE consumption in the country and based on this literature the current study has made the hypothesis as follows:

H4: There is positive nexus among the FDI and consumption of RE in ASEAN countries. 


\section{Innovation and Consumption of RE}

The use of RE is depended upon the innovation in which a country needs more products to sell in the market, and for the production of that product, the country uses the RE. Thus, innovation is considered a vital source of high RE consumption in the country and based on this literature the current study has made the hypothesis as follows:

H5: There is positive nexus among the innovation and consumption of RE in ASEAN countries.

\section{RESEARCH METHODS}

The foremost purpose of the paper is to investigate the role of international trade, real output, financial development, FDI, and innovation on the consumption of RE in ASEAN countries. Data were gathered from the World Bank for the year 1991 to 2015 to explain the nexus among the predictors and main constructs of the study. "Generalized Methods Movement (GMM)" has been used to test the hypotheses of the study after checking the assumptions of the regression and develops the following equation:

$$
R E C_{2 i t}=\alpha_{0}+\beta_{1} I T_{i t}+\beta_{2} R O_{i t}+\beta_{3} F D_{i t}+\beta_{4} F D I_{i t}+\beta_{4} I N_{i t} e_{i t}
$$

Where

$$
\begin{aligned}
& i=\text { Country } \\
& t=\text { time period } \\
& \text { REC }=\text { Renewable Energy Consumption } \\
& \text { RO = Real Output } \\
& \text { FD = Financial Development } \\
& \text { FDI = Foreign Direct Investment } \\
& \text { IN = Innovation } \\
& \text { IT = International Trade }
\end{aligned}
$$

\section{FINDINGS}

The outcomes of the study deal with assumptions of the regressions and the GMM estimator to test the hypotheses. The first assumption deals with the multicollinearity that is verified through VIF and found no high correlation between the variables because VIF is less than 0.05 and tolerance is less than 5. Table 2 shows the VIF given below:

Table 2: Variance Inflation Factor (VIF)

\begin{tabular}{|c|c|c|}
\hline & VIF & 1/VIF \\
\hline FD & 3.44 & .291 \\
\hline FDI & 2.935 & .341 \\
\hline RO & 2.022 & .494 \\
\hline IN & 1.623 & .616 \\
\hline IT & 1.082 & .924 \\
\hline Mean VIF & 2.221 &. \\
\hline
\end{tabular}


The second assumption deals with the normality of the data that is verified by using the Skewness and Kurtosis test, and results indicated that data is not normal because the values of the probabilities are less than 0.05 , which reject null hypothesis. The data normality problem does not affect the results because the observations are more than 100 and consider large. Table 2 shows the Skewness, and Kurtosis test is given below:

Table 3: Skewness and Kurtosis

\begin{tabular}{|c|c|c|c|c|c|}
\hline Variable & Obs & Pr(Skewness) & Pr(Kurtosis) & adj_chi2(2) & Prob>chi2 \\
\hline REC & 250 & 0.311 & 0.036 & 5.420 & 0.066 \\
\hline FDI & 250 & 0.984 & 0.011 & 6.340 & 0.042 \\
\hline RO & 250 & 0.083 & 0.062 & 6.310 & 0.043 \\
\hline IT & 250 & 0.208 & 0.000 & 27.660 & 0.000 \\
\hline IN & 250 & 0.000 & 0.000 &. & 0.000 \\
\hline FD & 250 & 0.000 & 0.000 &. & 0.000 \\
\hline
\end{tabular}

The third assumption regarding the regression homoscedasticity is verified by the Breusch Pagan test, and findings show that data has heteroscedasticity problem while fourth assumption about serial correlation is verified by Wooldridge test and finding show that data has serial correlation problem and both issues fix by using GMM approach.

The path analysis shows that the significant positive nexus among the international trade, real output, financial development, FDI, innovation, and consumption of RE because $\mathrm{p}$ values are less than 0.05, and t values are higher than 1.96. Table 4 shows the path analysis is given below:

Table 4: Path Analysis (GMM Estimator)

\begin{tabular}{|c|c|c|c|c|c|c|}
\hline CO2 & Coef & Std. Err & $\mathbf{t}$ & $\mathbf{p}$ & L.L & U.L \\
\hline IT & 0.017 & 0.002 & 7.530 & 0.000 & 0.012 & 0.022 \\
\hline FDI & 1.035 & 0.019 & 55.340 & 0.000 & 0.994 & 1.076 \\
\hline RO & 1.013 & 0.007 & 151.200 & 0.000 & 1.028 & 0.998 \\
\hline IN & 0.023 & 0.004 & 5.810 & 0.000 & 0.014 & 0.031 \\
\hline FD & 0.001 & 0.001 & 2.700 & 0.021 & 0.000 & 0.003 \\
\hline cons & -0.077 & 0.020 & -3.760 & 0.003 & -0.122 & -0.032 \\
\hline
\end{tabular}

\section{DISCUSSIONS AND CONCLUSIONS}

Public policy plays an important role in fostering innovation by establishing the "rules of the game." These include the rule of law, property rights, patent protections, contracts, free trade policies, freedom to travel, various incentives to invest, and light-touch regulations and regulatory regimes. When it comes to new technologies, the policy default should be permissionless innovation rather than restrictive regulations.

The foremost purpose of the paper is to investigate the role of international trade, real output, financial development, FDI, and innovation on the consumption of RE in ASEAN countries. The findings show that the significant positive nexus among international trade, real output, financial development, FDI, innovation, and consumption of RE. In the long run, the perpetual search for new and better ways of doing things drives human learning and, ultimately, prosperity for all.

Therefore, the current study concluded that the import and export of the ASEAN countries are at the peak, high financial development and innovation have been seen in the countries, and FDI and real output are also at high level that needs to use of RE to produce the goods for the fulfillment of the requirement. 
This study also implies further researches to recommend more effective solutions for the linkage between FDI and financial development for renewable energy for economic growth in a sustainable direction.

\section{REFERENCES}

1. Abidin, I. S. Z., Haseeb, M., Azam, M., \& Islam, R. (2015). Foreign direct investment, financial Development, international trade and energy consumption: Panel data evidence from selected ASEAN Countries. International Journal of Energy Economics and Policy, 5(3), 841-850.

2. Anton, S.G., \& Nucu, A.E.A. (2020). The effect of financial development on renewable energy consumption. A panel data approach, Renewable Energy, 147(1).

3. Barbier, E. B., Barbier, J. C. B., Bishop, J., \& Aylward, B. (2019). The economics of the tropical timber trade: Routledge.

4. Beck, T., Demirgü̈c-Kunt, A., \& Levine, R. (2010). Financial institutions and markets across countries and over time: The updated financial development and structure database. The World Bank Economic Review, 24(1), 77-92.

5. Dogan, E. (2016). Analyzing the linkage between renewable and non-renewable energy consumption and economic growth by considering structural break in time-series data. Renewable energy, 99, 1126-1136.

6. Dogan, E., \& Turkekul, B. (2016). CO 2 emissions, real output, energy consumption, trade, urbanization and financial development: testing the EKC hypothesis for the USA. Environmental Science and Pollution Research, 23(2), 1203-1213.

7. Eren, B.M., Taspinar, N., \& Gokmenoglu, K.K. (2019). The impact of financial development and economic growth on renewable energy consumption: Empirical analysis of India. Science of The Total Environment, 663(1), 189-197

8. Jensen, C. (2017). International trade in infant industries: A dynamic analysis of different trade policy instruments and their implications for sustainable consumption. International Trade in Infant Industries (2016), DOI, 10, 0935-9915.

9. Liu, X., Zhang, S., \& Bae, J. (2017). The impact of renewable energy and agriculture on carbon dioxide emissions: investigating the environmental Kuznets curve in four selected ASEAN countries. Journal of cleaner production, 164, 12391247.

10. Liu, W., Xu, X., Zhang, Z., Zhao, Chi., \& Xing, J. (2016). Impacts of FDI Renewable Energy Technology Spillover on China's Energy Industry Performance. Sustainability, 8.

11. Nadia, D., \& Seema, N. (2019). Does FDI influence renewable energy consumption? An analysis of sectoral FDI impact on renewable and non-renewable industrial energy consumption. Energy Economics, 54.

12. OECD. (2002). Foreign Direct Investment for Development. Maximising Benefits, Minimising Costs.

13. Olokoyo, F.O. (2012). Foreign Direct Investment and Economic Growth: A Case Study of Nigeria. BVIMSR'S Journal of Management Research, 4(1-30).

14. Pata, U. K. (2018). Renewable energy consumption, urbanization, financial development, income and CO2 emissions in Turkey: testing EKC hypothesis with structural breaks. Journal of cleaner production, 187, 770-779.

15. Polat, B. (2018). The Influence of FDI on Energy Consumption in Developing and Developed Countries: A Dynamic Panel Data Approach. Journal of Yasar University, 2018, 13(49), 33-42

16. Tang, C. F., \& Tan, B. W. (2015). The impact of energy consumption, income and foreign direct investment on carbon dioxide emissions in Vietnam. Energy, 79, 447-454.

17. Teleke, S., Baran, M. E., Bhattacharya, S., \& Huang, A. Q. (2010). Rule-based control of battery energy storage for dispatching intermittent renewable sources. IEEE Transactions on Sustainable Energy, 1(3), 117-124. 
18. Valodk, I., \& Valodkiene, G. (2015). The Impact of Renewable Energy on the Economy of Lithuania, Procedia - Social and Behavioral Sciences, 213, $123-128$.

19. Sara, Zatir, and Benkoula Sidi Mohammed El Habib. "The Impact of Renewable Energy in Urban Planning Instruments the Case of the Pdau." IMPACT: International Journal of Research in Engineering \& Technology (IMPACT: IJRET) 2.7 (2014): 123-126.

20. Al-Edary, Adnan Dawood M., and Wisam Neamah Jaafar. "The Impact FDI on Economics and Social Indictors in Pakistan Country." International Journal of Business and General Management (IJBGM) 5.2 (2016):61-76

21. Ajaegbu, Charles Chidozie. "Promoting foreign direct investment (FDI): The case of Uganda." IMPACT: International Journal of Research in Business Management (IMPACT: IJRBM) 2.4 (2014): 73-94.

22. Ajaegbu, Charles Chidozie. "The Ugandan Aproach to the Facilitation of Foreign Direct Investment (FDI): The Need for Some Adjustments." BEST: International Journal of Management, Information Technology and Engineering (BEST: IJMITE) 2.12 (2014): 19-34. 